\title{
Peran Wartawan Dalam Perlindungan Hak Anak Perspektif Undang-Undang Pers
}

\section{The Role of Journalists in Protecting Children's Rights Press Law Perspective}

\author{
Dedi Sahputra \\ Program Studi Ilmu Komunikasi, Fakultas Ilmu Sosial Ilmu Politik, \\ Universitas Medan Area, Indonesia
}

Diterima: 22 Mei 2021; Direview: 22 Mei 2021; Disetujui: 25 November 2021

\begin{abstract}
Abstrak
Dalam pemberitaan media massa terkait anak yang berkonflik dengan hukum, hak-hak anak harus tetap dilindungi. Oleh karenanya wartawan dalam menghasilkan karya jurnalistik dan media massa yang menyebarluaskan informasi tentang anak yang berkonflik dengan hukum harus merahasiakan identitas anak, baik anak sebagai pelaku, anak sebagai korban, dan anak sebagai saksi, serta segala informasi terkait anak tersebut. Dalam proses menghasilkan karya jurnalistik, suatu lembaga pers memiliki proses flow of copy yang merupakan suatu mekanisme untuk menjamin terpenuhinya unsur check and balance atas suatu informasi yang dihasilkan. Selain itu, ada pula mekanisme hak jawab di media massa yang mengatur jika terjadi pelanggaran dalam karya jurnalistik sebagaimana diamanatkan dalam UU Pers dan Kode Etik Jurnalistik. Mekanisme ini diatur tidak lain adalah untuk menjamin kebebasan pers dalam menjalankan fungsi pers yang esensi dalam kehidupan berbangsa dan bernegara. Dengan mekanisme hak jawab ini, pers yang menerbitkan karya jurnalistik yang melanggar hak-hak anak yang berkonflik dengan hukum, tetap harus bertanggungjawab tanpa harus melibatkan aspek hukum pidana di dalamnya.

Keywords: Kebebasan Pers; Produk Jurnalistik; Hak-hak Anak yang Berkonflik Dengan Hukum.
\end{abstract}

Abstrack

In the mass media coverage of children in conflict with the law, children's rights must be protected. Therefore journalists in producing journalistic works and mass media that disseminate information about children in conflict with the law must keep the identity of the child, both the child as the perpetrator, the child as the victim, and the child as a witness, as well as all information related to the child. In the process of producing journalistic work, a press institution has a flow of copy process which is a mechanism to ensure the fulfillment of checks and balances on the information produced. In addition, there is also a right of reply mechanism in the mass media that regulates if violations occur in journalistic work as mandated in the Press Law and Journalistic Code of Ethics. This mechanism is regulated is nothing but to guarantee the freedom of the press in carrying out the functions of the press which is essential in the life of the nation and state. With this right of reply mechanism, the press that publishes journalistic works that violate the rights of children in conflict with the law, must still be responsible without having to involve aspects of criminal law in it.

Keywords: Press Freedom; Journalistic Products; Children's Rights in Conflict with Law.

How to Cite: Sahputra, D. (2022). Peran Wartawan Dalam Perlindungan Hak Anak Perspektif Undang-Undang Pers. PERSPEKTIF 11(1): 25-34 


\section{PENDAHULUAN}

Dalam hubungan di antara hak-hak anak yang berkonflik dengan hukum dengan produk jurnalistik, terjadi suatu dilemma dalam aspek hukum yang muncul. Dalam interaksi di antara keduanya, pada satu sisi, anak-anak yang berkonflik dengan hukum memiliki hak-hak yang perlu dilindungi sebagaimana amanat Undang-Undang Nomor 11 tahun 2012 tentang Sistem Peradilan Pidana Anak (SPPA). Di lain sisi, pers mesti dijaga kebebasannya sebagai suatu prasyarat sebuah negara demokrasi yang sehat.

Undang-Undang Nomor 40 Tahun 1999 tentang Pers sesungguhnya telah mengatur suatu mekanisme jika terjadi pelanggaran dalam produk jurnalistik. Salah satu indikator kebebasan pers adalah dari mekanisme hak jawab. Dengan kata lain, dalam hukum pers yang berlaku selama ini, bahwa sanksi dalam pelanggaran hukum pers adalah mekanisme dalam hukum pers itu sendiri.

Mekanisme hak jawab dalam hukum pers adalah untuk menjamin kebebasan pers. Kebebasan pers merupakan sebuah keniscayaan untuk berdirinya negara demokrasi yang menjamin berbagai aspirasi dari berbagai elemen bangsa dapat tersalurkan. Untuk menjamin keberlangsungan demokrasi maka iklim pers yang sehat mesti dilestarikan (Sahputra, 2020).

Kebebasan pers di Indonesia sejak dulu sepuluh tahun belakangan, menghadapi hambatan serius. Gangguan pemilik media di ruang redaksi dianggap sebagai salah satu kendala paling serius ( Lesmana, 2017). Pada kenyataannya, kebebasan pers secara global telah menurun ke level terendah dalam 13 tahun, berkat ancaman baru bagi jurnalis dan outlet media di negara demokrasi utama, dan untuk penumpasan lebih lanjut terhadap media independen di negara-negara otoriter seperti Rusia dan Cina ( Abramowitz, 2017).

Begitu juga dengan situasi kebebasan pers di Indonesia. Ketua Aliansi Jurnalis Indonesia (AJI) Abdul Manan mencatat kebebasan pers di Indonesia masih memburuk. Diketahui, pada 2018 Indeks Kebebasan Pers (IKP) Indonesia hanya menduduki peringkat 124 dari 180 negara dalam Indeks Kebebasan Pers Dunia Tahun 2018 versi Reporters Without Borders. Bahkan peringkat IKP Indonesia lebih rendah disbanding Timor Leste yang menempati peringkat 93 (Suparman, 2019)

Situasi kondisi global ini semakin diperburuk dengan berbagai aksi pengekangan aspirasi publik melalui saluran media sosial. Pada tahun 2016, pemerintah yang represif terus menggunakan pemadaman media sosial dan layanan internet untuk membatasi aliran informasi dan membungkam perbedaan pendapat. Paling sering, pihak berwenang menutup akses ke situs web dan aplikasi komunikasi di saat pergolakan politik atau pemilihan di sekitarnya, membatasi kemampuan jurnalis dan publik untuk berbagi berita tentang peristiwa penting. Selain melanggar hak dasar warga negara atas akses ke informasi, pembatasan ini berfungsi untuk menghindari pelanggaran negara dari catatan publik dan menyembunyikan secara potensial.

Dalam hal penanganan hukum anak yang berkonflik dengan hukum mengedepankan penerapan diversi. Hak-hak anak tersebut perlu dilindungi untuk tujuan keadilan. Penerapan diversi terhadap anak yang berhadapan dengan hukum dalam sistem peradilan anak merupakan implementasi sistem dalam restorative jusctice untuk memberikan keadilan dan perlindungan hukum kepada anak yang berkonflik dengan hukum tanpa mengabaikan pertanggungjawaban pidana anak (Hambali, 2019).

Dalam penanganan anak yang berhadapan dengan hukum melalui sistem peradilan pidana anak yang dimulai dari tahap penyelidikan sampai dengan tahap pembimbingan melibatkan peranan aparat penegak hukum mulai dari peranan kepolisian, kejaksaan, hakim serta BAPAS. Keempat komponen penegak hukum tersebut bekerja dalam sistem peradilan pidana anak yang mengacu pada komponen dari sistem peradilan pidana, namun dengan tetap mengedepankan kepentingan dan kesejahteraan anak. Penghindaran hukuman pidana kepada anak melalui penerapan diversi dalam sistem peradilan anak sebagai bentuk perlindungan anak dari pengalaman yang pahit berupa stigmatisasi (cap negatif) berkepanjangan, dehumanisasi (pengasingan dari masyarakat) dan menghindarkan anak dari kemungkinan terjadinya prisionisasi yang menjadi sarana transfer kejahatan terhadap anak.(Mareta, 2016). 
Sementara itu kecenderungan jumlah anak yang berkonflik dengan hukum mengalami peningkatan dari tahun ke tahun. Berdasarkan data dari Komisi Perlindungan Anak Indonesia (KPAI), sejak 2011 sampai 2019, jumlah kasus anak yang berhadapan dengan hukum yang dilaporkan ke KPAI mencapai angka 11.492 kasus, jauh lebih tinggi daripada laporan kasus anak terjerat masalah kesehatan dan Napza (2.820 kasus), pornografi dan cyber crime (3.323 kasus), serta trafficking dan eksploitasi (2.156 kasus). Angka anak yang berhadapan dengan hukum karena menjadi pelaku kekerasan seksual juga cenderung melonjak tajam. Pada 2011, pelaku kejahatan seksual anak ada pada angka 123 kasus. Angka tersebut naik menjadi 561 kasus pada 2014, kemudian turun menjadi 157 kasus pada 2016, dan pada medio Januari sampai Mei 2019, angka kasus anak yang berhadapan dengan hukum sebagai pelaku kekerasan seksual mencapai 102 kasus. Sedangkan laporan anak yang berhadapan dengan hukum karena menjadi pelaku kekerasan fisik dan psikis mencapai 140 kasus pada tahun 2018 (suara.com, 2020).

Sedangkan data dari World Health Organization (WHO) tahun 2016 menunjukkan bahwa (Mardina, 2018): Satu dari 4 orang dewasa melaporkan pernah mengalami kekerasan saat usia anak/remaja; 1 dari 5 perempuan dan 1 dari 13 laki-laki pernah mengalami kekerasan seksual saat usia anak/remaja; $12 \%$ anak-anak di dunia mengalami kekerasan seksual pada satu tahun terakhir; $37 \%$ dari negara anggota WHO menerapkan intervensi pencegahan kejadian kekerasan seksual pada skala yang lebih besar.

Senada dengan itu, laporan Unicef tahun 2015 kekerasan terhadap anak terjadi secara luas di Indonesia; 40\% anak berusia 13-15 tahun melaporkan pernah diserang secara fisik sedikitnya satu kali dalam setahun, 26\% melaporkan pernah mendapat hukuman fisik dari orang tua atau pengasuh di rumah, dan $50 \%$ anak melaporkan di-bully di sekolah (Mardina, 2018).

Dalam rangka mengatasi permasalahan anak ini, Pemerintah Indonesia, di samping mengeluarkan Keputusan Presiden dan Undang Undang Perlindungan Anak sebagaimana dipaparkan di atas, ada juga Undang-Undang Nomor 11 Tahun 2012 tentang Sistem Peradilan Pidana Anak (SPPA) yang mengatur mengenai anak peradilan anak yang berhadapan dengan hukum. Namun sejak diundangkannya undang-undang ini, tidak berjalan sebagaimana mestinya, karena pada umumnya kalangan masyarakat, aparat penegak hukum (Hakim, polisi dan jaksa), belum sepenuhnya mengetahui akan keberadaan Undang-undang ini. Kalangan masyarakat pada umumnya, masih dominan menyelesaikan perkara anak-anak, dengan sistem yang lama, anak yang bersalah harus dipenjara kita (dikurung), tidak dengan diversi sebagaimana dimaksudkan undang-undang (Pardede, 2017)

Peraturan perundang-undangan yang diterbitkan oleh pemerintah adalah bagian dari peran negara dalam mengurusi masyarakatnya. Karena memang jika membicarakan negara, sebenarnya kita membicarakan masyarakat manusia (Lubis, 2014). Dalam hal ini negara hadir untuk melindungi hak-hak anak yang berhadapan dengan hukum.

Namun peran negara ini tidak terlepas dari politik hukum yang berlangsung. Tujuan negara sebagai arah pembangunan nasional sejalan dan berkaitan erat dengan politik hukum yang berlaku dan berubah-ubah. Peranan Politik hukum nasional sangatlah penting dalam mencapai tujuan negara (Fitriana, 2015)

Berdasarkan uraian di atas terlihat peran wartawan dalam melindungi hak-hak anak yang berkonflik dengan hukum. Wartawan memiliki peran penting untuk tidak menyebarluaskan identitas anak yang berkonflik dengan hukum dalam rangka terpenuhinya hak-hak anak mereka.

Masalah dalam penelitian ini adalah bagaimanakah peranan wartawan dalam melindungi hak-hak anak yang berkonflik dengan hukum sebagaimana yang diatur dalam Undang-undang nomor 11 tahun 2012 tentang Sistem Peradilan Pidana Anak, dan bagaimana pula mekanisme hukum dalam tubuh pers terkait dalam proses mencari, mengolah, dan menyiarkan informasi yang berkaitan dengan anak yang berkonflik dengan hukum.

\section{METODE PENELITIAN}

Pendekatan dalam penelitian ini adalah pendekatan yuridis-normatif yang dilakukan dengan mengumpulkan dan menganalisis berbagai informasi yang berkaitan dengan permasalahan yang dibahas secara kualitatif. 
Selain itu, penelitian ini juga didukung dengan metode perbandingan hukum dan penafsiran hukum untuk dapat mengetahui pelaksanaan peranan wartawan dalam melindungi hak-hak anak yang berkonflik dengan hukum, serta untuk mengetahui mekanisme hukum pers yang berlaku selama ini dalam memproses pelanggaran penyiaran informasi oleh media massa. Berbagai informasi dan data-data yang dikumpulkan dan dianalisis dalam penelitian ini dilakukan penelusuran melalui berbagai literature kajian ilmiah dan juga dari peraturan perundang-undangan, serta mekanisme hukum pers yang berlaku di media massa.

\section{HASIL DAN PEMBAHASAN}

\section{Peran Wartawan Dalam Undang-undang Sistem Peradilan Pidana Anak}

Dalam Undang-Undang Nomor 11 Tahun 2012 tentang Sistem Peradilan Pidana Anak dijelaskan bahwa anak yang berkonflik dengan hukum, juga termasuk anak yang menjadi korban dan anak yang menjadi saksi sebagaimana bunyi pasal 1 (2): Anak yang Berhadapan dengan Hukum adalah anak yang berkonflik dengan hukum, anak yang menjadi korban tindak pidana, dan anak yang menjadi saksi tindak pidana.

Selanjutnya pada pasal 19 ayat (1) disebutkan: Identitas Anak, Anak Korban, dan/atau Anak Saksi wajib dirahasiakan dalam pemberitaan di media cetak ataupun elektronik. (2) Identitas sebagaimana dimaksud pada ayat (1) meliputi nama Anak, nama Anak Korban, nama Anak Saksi, nama orang tua, alamat, wajah, dan hal lain yang dapat mengungkapkan jati diri Anak, Anak Korban, dan/atau Anak Saksi.Undang-Undang Republik Indonesia Nomor 11 Tahun 2012 Tentang Sistem Peradilan Pidana Anak.

Dalam prakteknya, wartawan dalam menyiarkan informasi tentang anak yang berhadapan dengan hukum, baik anak sebagai tersangka/terdakwa/pelaku, anak sebagai korban, maupun anak sebagai saksi, wajib untuk merahasiakan identitas anak meliputi:

Pertama, nama anak. Nama anak yang berhadapan dengan hukum wajib disamarkan, dengan menggunakan inisial tertentu yang tidak menuntun publik untuk mengenali nama si anak tersebut.

Kedua, wajah anak. Wajah anak baik dalam foto atau pun video tidak boleh disiarkan secara jelas. Jikalau hendak disiarkan untuk kepentingan pemberitaan, maka wajib untuk disamarkan/blur sehingga orang yang melihatnya tidak dapat mengenali wajah si anak tersebut.

Ketiga, alamat anak. Alamat anak dari mulai nama jalan gang/lorong, RT/RW/Lingkungan, desa/kelurahan wajib dirahasiakan termasuk alamat e-mail, dan alamat pada akun media sosial seperti facebook, twitter, instagram dan lainnya, karena penyebarluasan informasi alamat tersebut dapat menuntun publik mengenali identitas si anak tersebut. Alamat anak yang dapat disiarkan untuk kepentingan pemberitaan adalah sampai pada batas kecamatan. Misalnya: Tersangka Sy (15 tahun), warga Kecamatan Medan Sunggal...

Keempat, nama dan alamat sekolah. Nama dan alamat sekolah secara rinci untuk harus dirahasiakan oleh wartawan dalam pemberitaan media massa. Karena nama dan alamat sekolah dapat menuntun publik mengenali si anak. Alamat sekolah anak yang berhadapan dengan hukuk yang dapat disiarkan untuk kepentingan pemberitaan adalah sampai pada batas kecamatan. Misalnya: Tersangka Sy (15 tahun), murid salah satu sekolah di Kecamatan Medan Sunggal...

Kelima, identitas keluarga. Identitas keluarga seperti ayah, ibu, adik/kakak paman, kakek/nenek juga tetangga anak yang berhadapan dengan hukum juga wajib untuk dirahasiakan. Identitas tersebut termasuk nama, wajah, alamat, tempat bekerja dan sebagainya. Dalam hal anak menjadi korban/pelaku pelanggaran hukum oleh keluarga dekat seperti ayah, maka segala identitas sang ayah harus dirahasiakan. Karena pengungkapan identitas tersebut melalui pemberitaan dapat menuntun publik mengenali si anak tersebut.

Selanjutnya, hal yang juga menjadi perhatian dari undang-undang ini adalah mengenai batas usia anak yang berhadapan dengan hukum. Pasal 1 ayat 3 (tiga) disebutkan: Anak yang Berkonflik dengan Hukum yang selanjutnya disebut Anak adalah anak yang telah berumur 12 (dua belas) tahun, tetapi belum berumur 18 (delapan belas) tahun yang diduga melakukan tindak pidana.(UndangUndang Nomor 11 Tahun 2012 Tentang Sistem Peradilan Pidana Anak, n.d.) Begitu juga dengan bunyi Undang-Undang Nomor 35 Tahun 2014 tentang Perubahan Atas Undang- 
Undang Nomor 23 Tahun 2002 tentang Perlindungan Anak. Pada Pasal 1 angka 1 UU Perlindungan Anak menyebutkan bahwa anak adalah seseorang yang belum berusia 18 (delapan belas) tahun, termasuk anak yang masih dalam kandungan.(Undang Undang Republik Indonesia Nomor 23 Tahun 2002 Tentang Perlindungan Anak, n.d.)

Perubahan batas usia anak ini berdampak pada pola penyebaran informasi melalui media massa, termasuk terkait informasi tentang anak yang berhadapan dengan hukum. Karena berdasarkan Kode Etik Jurnalistik, yang selama ini dipedomani para wartawan dalam menulis berita, bahwa yang dimaksud dengan anak adalah sebagaimana pasal 5 (b) Kode Etik Jurnalistik yang berbunyi: Wartawan Indonesia tidak menyebutkan dan menyiarkan identitas anak korban kejahatan susila dan tidak menyebutkan identitas anak yang menjadi pelaku kejahatan; (b) anak adalah seorang yang berusia kurang dari 16 tahun dan belum menikah (Kode Etik Jurnalistik, n.d.)

Melengkapi perkembangan hukum pers yang terjadi terkait dengan pemberitaan menyangkut anak, Dewan Pers telah pula mengeluarkan Pedoman Pemberitaan Ramah Anak (PPRA) pada Februari 2019. Pada poin 1 PPRA berbunyi: Wartawan merahasiakan identitas anak dalam memberitakan informasi tentang anak khususnya yang diduga, disangka, didakwa melakukan pelanggaran hukum, atau dipidana atas kejahatannya.

Dari bunyi Kode Etik Jurnalistik dan Pedoman Pemberitaan Ramah Anak dibandingkan dengan Undang-Undang Nomor 11 Tahun 2012 tentang Sistem Peradilan Pidana Anak dan Undang-Undang Nomor 23 Tahun 2002 tentang Perlindungan Anak terdapat beberapa konsekuensi bagi pedoman pemberitaan yang dilakukan wartawan:

Pertama, batas usia anak diperluas dari seorang yang berusia kurang dari 16 tahun dan belum menikah, menjadi seorang yang belum berusia 18 tahun. Wartawan dalam pemberitaan terhadap orang-orang yang berkonflik dengan hukum harus memperhatikan persoalan usia kategori anak. Sehingga setiap orang yang bermasalah dengan hukum yang masuk dalam kategori anak, mesti disamarkan segala identitasnya.

Kedua, pengertian anak yang berhadapan dengan hukum diperluas dari anak korban kejahatan susila dan anak yang menjadi pelaku kejahatan, menjadi anak yang menjadi korban, anak yang menjadi pelaku dan anak yang menjadi saksi.

Pemberlakuan aturan hukum ini memiliki konsekuensi bahwa wartawan dapat dipidana jika dalam pemberitaannya melanggar PPRA. Hal ini sebagaimana bunyi Pasal 97 UndangUndang Nomor 11 Tahun 2012 tentang Sistem Peradilan Pidana Anak, yang berbunyi: Setiap orang yang melanggar kewajiban sebagaimana dimaksud dalam Pasal 19 ayat (1) dipidana dengan pidana penjara paling lama 5 (lima) tahun dan denda paling banyak Rp500.000.000,00 (lima ratus juta rupiah). Dengan demikian Undang Undang Pers No 40 Tahun 1999 bukan sebagai lex specialis dan produk jurnalistik yang melanggar peraturan perundang-undangan dapat dipidana (Sahputra, 2019).

Dengan kata lain pemberitaan di media massa yang melanggar hak-hak anak yang berkonflik dengan dengan hukum dapat dihukum dengan hukuman pidana. Hal ini bermakna bahwa produk jurnalistik dapat dijerat dengan hukum pidana. Bahwa pelanggaran dalam produk jurnalistik tidak dihukum dengan produk jurnalistik pula, namun dihukum dengan hukuman pidana.

Lantas mengapa anak harus memiliki hak sendiri dibandingkan dengan orang dewasa? Anak-anak yang berada di bawah usia 7 tahun dianggap tidak memiliki keinginan untuk melakukan tindakan kriminal (incapable of having the criminal intent), sedangkan anakanak yang berada di kisaran usia 7 sampai 14 tahun pada umumnya memiliki keinginan untuk melakukan tindakan kriminal, berarti anak tidak mampu melakukan kriminalitas (incapable of crime). Kondisi psikologis merupakan suatu keadaan psikis yang tidak tampak oleh mata dan mendasari seseorang untuk berperilaku secara sadar. Kondisi psikologis yang mempengaruhi seseorang untuk berperilaku juga dipengaruhi oleh struktur kepribadiannya (Irmayani, 2017).

Anak yang belum berusia dewasa yang berhadapan dengan hukum harus dilindungi hak-haknya. Karena seringkali remaja mengambil keputusan yang keliru pada peristiwa tertentu. Penyebab dari pengambilan keputusan tersebut dipengaruhi oleh keinginan yang serba emosional yang tidak jarang bersifat irasional dan tidak bermoral. Perkembangan moralitas pada remaja juga merupakan hal 
yang tidak dapat dilupakan dalam masa transisi ini. Moralitas adalah usaha untuk membimbing tindakan seseorang dengan akal untuk memilih dan melakukan yang baik menurut akal dan orang lain yang menyangkut kepentingan tersebut (Ginting \& Santoso, 2019).

Bila rasa bersalah muncul dalam diri pelaku maka akan ada kemungkinan munculnya penyesalan pada diri mereka. Hal ini karena remaja nakal, terlebih yang telah melakukan tindak kriminalitas dianggap telah melakukan suatu pelanggaran terhadap standar internal individu serta merupakan pelanggaran terhadap peraturan sosial, moral atau etika yang ada dalam masyarakat, maka akan ada kemungkinan munculnya penyesalan pada diri mereka (Utami \& Asih, 2016).

Kesehatan mental anak dipengaruhi oleh lingkungannya. Tinjauan sistematis mengungkapkan hubungan yang signifikan antara risiko dari masyarakat dan faktor pelindung dengan kesehatan mental anak dan remaja. Dengan meningkatnya prevalensi terkait masalah kesehatan mental anak, maka promosi kesehatan masyarakat dan intervensi awal diperlukan untuk meminimalkan dampak gejala depresi pada anak (Stirling et al., 2015).

Hak-hak anak telah menjadi bagian integral dalam pemerintahan dan regulasi anak-anak, keluarga dan masyarakat di seluruh dunia. Gagasan tata kelola hak anak karenanya tidak hanya harus dipahami lintas waktu (temporal) dan ruang (spaitas) tetapi juga dalam kaitannya dengan gagasan dan praktik pemerintah (subjektivitas) dari mereka yang diberikan hak (Holzscheiter et al., 2019).

\section{Mekanisme Hukum Pers Dalam UU Pers}

Pada bagian lain, wartawan adalah pihak yang berperan penting dalam distribusi informasi yang berdasarkan prinsip-prinsip keseimbangan (check and balance) dalam pemberitaan di media massa. Dalam mekanisme penyebarluasan informasi di media massa ada flow of copy atau proses sebuah informasi menjadi berita sebelum dapat disiarkan. Hasil wawancara dengan Edward Thahir, Redaktur Pelaksana Harian Waspada Medan, proses ini secara umum lazimnya meliputi mekanisme sebagai berikut:

Dimulai dari rapat proyeksi di pagi hari untuk merencanakan kegiatan liputan yang akan dilakukan, liputan wartawan ke lapangan pada hari tersebut. Rapat biasanya dipimpin oleh chief reporter yang bertanggungjawab mengembangkan informasi hingga menjadi berita yang akan disuguhkana kepada khalayak,

Selanjutnya adalah proses listing dan pembuatan berita. Para wartawan kemudian membuat listing atau daftar informasi yang didapatnya dari lapangan untuk ditulis menjadi berita oleh wartawan dan akan mengikuti proses selanjutnya sebelum diterbitkan.

Kemudian berlanjut, berita yang sudah ditulis oleh wartawan kemudian melalui proses editing oleh masing-masing redaktur terkait kelengkapan berita, termasuk dalam hal delik hukum pers dalam kandungan berita yang diseleksi. Berita yang telah diseleksi dapat langsung dimuat atau ditayangkan, tetapi bisa juga dikembalikan kepada wartawan pembuat berita untuk dilengkapi.

Sebelum pemuatan ada rapat budget untuk menentukan berita utama yang akan disiarkan dan pertimbangan redaktur untuk berita-berita lain yang akan dimuat.

Proses flow of copy sebagaimana dipaparkan di atas pada umumnya dipraktekkan di media cetak dan media elektronik seperti koran dan majalah serta radio dan televisi. Sedangkan untuk media siber memiliki mekanisme flow of copy yang sedikit berbeda dengan penayangan informasi yang dilakukan beberapa kali dalam satu hari, namun pada prinsipnya memiliki kesamaan dalam hal menjaga dan memastikan tidak adanya delik hukum atau pelanggaran hukum dari berita yang akan disebarluaskan. Delik hukum yang dimaksud merupakan etika pers dan prinsip-prinsip yang menjadi acuan sebagaimana diatur dalam Kode Etik Jurnalistik (KEJ), seperti:

Ketidakeseimbangan berita (cover both sides) sebagaimana pasal $1 \mathrm{KEJ}$; Bercampurnya fakta dengan opini yang menghakimi dalam berita sebagaimana pasal $3 \mathrm{KEJ}$; Mengabaikan asas praduga tak bersalah sebagaimana pasal 3 KEJ, dan pasal 5 UU Pers; Mengandung berita bohong, fitnah, sadis dan cabul sebagaimana pasal 4 KEJ; Menyebutkan dan menyiarkan identitas korban kejahatan susila dan menyebutkan identitas anak yang menjadi pelaku tindak kejahatan sebagaimana pasal 5 KEJ; Menulis berita berdasarkan prasangka atau diskriminasi terhadap seseorang atas dasar perbedaan suku, ras, warna kulit, agama, jenis kelamin dan bahasa serta merendahkan 
martabat orang lemah, miskin, sakit, cacat jiwa atau cacat jasmani sebagaimana pasal $8 \mathrm{KEJ}$.

Mekanisme flow of copy seperti ini berlaku secara umum atau untuk segala jenis berita, termasuk dalam liputan anak yang berkonflik dengan hukum. Melalui mekanisme seperti ini maka berita yang disajikan kepada masyarakat akan lebih terjamin terpenuhinya syarat-syarat sebuah berita di dalamnya. Mekanisme seperti ini juga menunjukkan bahwa informasi atau berita yang disajikan oleh media massa sesungguhnya adalah produk sebuah lembaga pers, dan kurang tepat untuk disebut sebagai produk wartawan secara orang perorang.

Mekanisme flow of copy pada intinya memberi jaminan adanya check and balance dalam setiap produk atau karya jurnalistik yang dihasilkan oleh media massa. Pelanggaran terhadap prinsip check and balance dalam produk jurnalistik, diselesaikan melalui mekanisme hak jawab yang telah difasilitasi oleh hukum pers, yaitu UU No.40 tahun 1999 tentang Pers dan Kode Etik Jurnalistik.

Karena prinsip-prinsip dalam menghasilkan karya jurnalistik seperti ini, media massa lebih dipercaya atau menjadi tempat mengonfirmasi atas informasiinformasi yang beredar secara luas dan massif melalui media lainnya, khususnya atas informasi yang beredar di media sosial. Karena memang prinsip-prinsip di media massa tersebut berbeda dengan proses yang terjadi di media sosial, di mana seorang pemilik akun dapat berfungsi sebagai wartawan, redaktur sekaligus pemilik otoritas penyiaran informasi. Informasi yang beredar di media sosial juga tidak melalui proses check and recheck atau melakukan konfirmai kepada pihak-pihak yang terlibat dalam informasi yang akan disiarkan. Akibatnya penyebaran informasi hoax terjadi secara massif di media sosial.

Salah satu penyebab hoax adalah saat ini adalah mewabahnya teknologi media sosial dan smartphone. Dalam realitasnya, hoax yang beredar di media sosial banyak yang mengarah ke ujaran kebencian.(Heryanto, 2018) Teknologi ini juga menghadapi persoalan keamanan. Transformasi digital juga membawa risiko. Tingginya perangkat yang terhubung ke jaringan IT meningkatkan kemungkinan sebuah organisasi mengalami masalah cyber security karena banyaknya titik masuk dari cyber attacks. Indonesia bahkan mengalami hampir 91 ribu infeksi malware $(26,3 \%$ dari infeksi global) pada tahun 2016 (Ramli et al., 2019).

Media sosial mengajak siapa saja yang tertarik untuk berpartisipasi dengan memberikan kontribusi dan feedback secara terbuka, serta membagi informasi dalam waktu yang cepat dan tidak terbatas (Tabroni, 2014). Dengan kata lain bahwa media sosial menekankan pada sifat feedback yang terbuka dan cepat serta tidak terbatas. Sedangkan prinsip check and balance tidak menjadi pertimbangan dalam lalulintas informasi melalui media sosial. Sifat media sosial seperti ini memiliki konsekuensi bahwa saringan atas informasi yang beredar menjadi sangat longgar. Informasi baru dapat dilakukan tindakan setelah beredar dan dilaporkan kepada manajemen media sosial bersangkutan. Dengan begitu berita-berita yang beredar adalah informasi yang tidak tervalidasi keabsahannya, baik yang kemudian bermasalah dengan hukum ataupun yang tidak bermasalah hukum.

Hal ini sekaligus menunjukkan bahwa media massa sesungguhnya memiliki peran yang sangat penting dalam penyebarluasan informasi. Media massa disadari maupun tidak, melalui proses komunikasi persuasif menanamkan kesadaran tertentu dalam benak khalayak (Nasrullah, 2019). Media massa menjadi referensi bagi berbagai tindakan dan perilaku khalayak, bahkan menjadi dasar bagi kebijakan umum (public policy) bagi para pengambil keputusan.

Hakim dalam menjatuhkan putusannya dapat mempertimbangkan berbagai macam faktor sebagai bahan pertimbangan untuk menjatuhkan putusan yang mereka buat berkaitan dengan perkara yang mereka tangani. Pemberitaan dari media massa bisa saja menjadi satu diantara faktor tersebut asalkan sesuai dengan kenyataan hukum yang terjadi dan sesuai dengan rasa keadilan dan kepastian hukum, tanpa mengabaikan/mengenyampingkan

independensi dan kenetralan hakim selaku pejabat negara dan aparat penegak hokum (Mardiansyah, 2015).

Undang-Undang No.11 tahun 2012 tentang Sistem Peradilan Pidana Anak (SPPA) telah secara resmi diadopsi menjadi salah satu hukum pers yang mengatur tentang lalu lintas informasi melalui media massa. Hal tersebut ditandai dengan diterbitkannya Peraturan 
Dewan Pers Nomor 1/Peraturan-DP/II/2019 tentang Pedoman Pemberitaan Ramah Anak (PPRA) pada tanggal 9 Februari 2019.

Peraturan Dewan Pers ini adalah turunan dari Undang-Undang Nomor 35 Tahun 2014 tentang Perubahan Atas Undang-Undang Nomor 23 Tahun 2002 tentang Perlindungan Anak, dan Undang-Undang Nomor 11 Tahun 2012 tentang SPPA.(Sahputra, 2019) Fokus dari PPRA yang kemudian menjadi pedoman bagi wartawan dalam meliput berita adalah mengenai batas usia anak yang berubah menjadi sebelum genap 18 tahun.

Adapun 12 butir Pedoman Pemberitaan Ramah Anak (PPRA) tersebut yakni:

1. Wartawan merahasiakan identitas anak dalam memberitakan informasi tentang anak khususnya yang diduga, disangka, didakwa melakukan pelanggaran hukum atau dipidana atas kejahatannya.

2. Wartawan memberitakan secara faktual dengan kalimat / narasi / visual / audio yang bernuansa positif, empati, dan/atau tidak membuat deskripsi/rekonstruksi peristiwa yang bersifat seksual dan sadistis.

3. Wartawan tidak mencari atau menggali informasi mengenai hal-hal di luar kapasitas anak untuk menjawabnya seperti peristiwa kematian, perceraian, perselingkuhan orangtuanya dan/atau keluarga, serta kekerasan atau kejahatan, konflik dan bencana yang menimbulkan dampak traumatik.

4. Wartawan dapat mengambil visual untuk melengkapi informasi tentang peristiwa anak terkait persoalan hukum, namun tidak menyiarkan visual dan audio identitas atau asosiasi identitas anak.

5. Wartawan dalam membuat berita yang bernuansa positif, prestasi, atau pencapaian, mempertimbangkan dampak psikologis anak dan efek negatif pemberitaan yang berlebihan.

6. Wartawan tidak menggali informasi dan tidak memberitakan keberadaan anak yang berada dalam perlindungan LPSK.

7. Wartawan tidak mewawancarai saksi anak dalam kasus yang pelaku kejahatannya belum ditangkap/ditahan.

8. Wartawan menghindari pengungkapan identitas pelaku kejahatan seksual yang mengaitkan hubungan darah/keluarga antara korban anak dengan pelaku. Apabila sudah diberitakan, maka wartawan segera menghentikan pengungkapan identitas anak. Khusus untuk media siber, berita yang menyebutkan identitas dan sudah dimuat, diedit ulang agar identitas anak tersebut tidak terungkapkan.

9. Dalam hal berita anak hilang atau disandera diperbolehkan mengungkapkan identitas anak, tapi apabila kemudian diketahui keberadaannya, maka dalam pemberitaan berikutnya, segala identitas anak tidak boleh dipublikasikan dan pemberitaan sebelumnya dihapuskan.

10. Wartawan tidak memberitakan identitas anak yang dilibatkan oleh orang dewasa dalam kegiatan yang terkait kegiatan politik dan yang mengandung SARA.

11. Wartawan tidak memberitakan tentang anak dengan menggunakan materi (video/foto/status/audio) dari media sosial.

12. Dalam peradilan anak, wartawan menghormati ketentuan dalam UndangUndang Sistem Peradilan Pidana Anak.

Berdasarkan keputusan Mahkamah Agung (MA) No. 1608/K/Pid/2005, UndangUndang Pers bersifat prima art atau prevail sehingga harus didahulukan. Pengimplementasian hukum pers dalam pemberitaan di media massa, pelanggaran hukum yang terjadi memiliki konsekuensi sesuai perangkat hukum yang dilanggar. Jika pemberitaan yang disiarkan melanggar Undang-Undang Pers Nomor 40 Tahun 1999 dan Kode Etik Jurnalistik maka konsekuensinya adalah sesuai dengan aturan hukum UndangUndang Pers dan Kode Etik Jurnalistik, yakni melalui mekanisme hak jawab (Sahputra, 2020).

Dalam Undang-Undang Pers tidak mengenal mengkriminalkan karya jurnalistik. Atas sengketa yang terjadi harusnya yang dilakukan bukan laporan pidana tapi sengketa pers. Dan berhak mengadu ke Dewan pers dulu bukan polisi. Jika ada pihak yang keberatan mengenai sebuah pemberitaan, ada hak jawab yaitu berupa koreksi. Nantinya dewan pers menilai apakah hasil jurnalistik tersebut ada unsur itikad baik atau buruk yang merugikan seseorang. Kalau ada pihak keberatan tentang suatu berita ada hak jawab dengan mengoreksi. Tulisan dibalas dengan tulisan, bukan balas dengan kriminalisasi. Pertanggungjawaban sebuah produk jurnalistik, ialah redaksi pada media tersebut. Jika produk pers itu 
bermasalah yang bertanggungjawab itu adalah redaksi. Di tangan redaksi itu sebuah pemberitaan akan terlihat hasilnya. Namun ada juga namanya hak tolak yang difungsikan untuk melindungi narasumber. Seperti tidak memberitahu nama atau identitas narasumber itu sendiri. Wartawan mempunyai hak tolak untuk melindungi narasumber (Jelita, 2018).

Mekanisme hak jawab yang selama ini berlaku dalam pelanggaran etika dan hukum pers efektif untuk meredam pelanggaran aturan dalam penyebaran informasi oleh media massa. Dewan Pers telah melengkapi dengan kompetensi wartawan dan verifikasi media massa sebagai institusi sebagai prasyarat sebagai sebuah lembaga pers. Dengan memenuhi prasyarat tersebut, maka sebuah lembaga yang menyebarluaskan informasi dapat dikatakan sebagai lembaga pers yang tunduk pada mekanisme hukum pers. Akan halnya lembaga penyiaran yang tidak terverifikasi, maka tidak dapat dikategorikan sebagai lembaga pers, namun merupakan suatu lembaga lain yang tidak berlaku baginya meksnisme hukum pers.

\section{SIMPULAN}

Peranan wartawan sangat penting dalam melindungi hak-hak anak yang berkonflik dengan hukum. Anak-anak perlu dilindungi hak-haknya ketika berhadapan dengan hukum, karena hal ini menyangkut masa depan anak, yang juga dapat bermakna menyangkut masa depan bangsa dan negara. Karena anak adalah generasi pewaris masa depan bangsa dan negara. Wartawan dalam pemberitaannya wajib melindungi identitas anak yang berhadapan dengan hukum, baik anak sebagai tersangka/terdakwa/pelaku, anak sebagai korban, maupun anak sebagai saksi. Mekanisme hak jawab telah mengatur jika terjadi pelanggaran dalam karya jurnalistik yang mengacu pada UU No.40 tahun 1999 tentang Pers dan Kode Etik Jurnalistik. Dari perspektif ini, mekanisme hak jawab telah cukup memadai dalam mengatur pelanggaran yang terjadi dalam karya jurnalistik tanpa memasukkan aspek hukum pidana dalam mengatur karya jurnalistik. Karena pers yang memiliki peran penting dalam kehidupan berbangsa dan bernegara dapat terus menjalankan fungsinya tanpa harus ada aspek hukum pidana dalam menghasilkan karya jurnalistik.

\section{DAFTAR PUSTAKA}

Fana S. (2019). Kebebasan Pers di Indonesia Memburuk. Beritasatu.Com. https://hukum.tempo.co/read/1059485/ke bebasan-pers-di-indonesia/full\&view $=\mathrm{ok}$

Ginting, P. A., \& Santoso, M. B. (2019). Perubahan Perilaku Anak Berhadapan Dengan Hukum (ABH). Social Work Journal, 9(1), 86-101. https://doi.org/10.24198/share.v9i1.21819

Hambali, A. R. (2019). Penerapan Diversi Terhadap Anak Yang Berhadapan dengan Hukum Dalam Sistem Peradilan Pidana. Jurnal Ilmiah Kebijakan Hukum, 13, 15-30. https://doi.org/http://dx.doi.org/10.30641 /kebijakan.2019.V13.15-30

Heryanto, G. G. (2018). Media Komunikasi Politik: Relasi Kuasa Media di Panggung Politik. IRCiSoD.

Holzscheiter, A., Josefsson, J., \& Sandin, B. (2019). Child rights governance: An introduction. Childhood, 26(3), 271-288. https://doi.org/10.1177/090756821985451 8

Irmayani. (2017). Peranan orang tua, penegak hukum dan pekerja sosial dalam mengatasi masalah psikososial anak yang berkonflik dengan hukum atau lembaga pemasyarakatan. Sosio Informa, 3(02), 138152.

Jelita, I. N. (2018). Produk Jurnalistik Tidak Bisa Dikriminalisasi. Mediaindonesia.Com.

Kode Etik Jurnalistik.

Lubis, S. (2014). Ilmu Negara Edisi Revisi (Cetakan ke). Mandar Maju.

Mardiansyah, A. (2015). Pengaruh Media Massa Terhadap Putusan Hakim Dalam Perkara Tindak Pidana Korupsi. Jurnal Legislasi Indonesia, 12(1), 1-14.

Mardina, R. (2018). Pusat Data dan Informasi Kementrian Kesehatan RI.

Mareta, J. (2016). Mekanisme Penegakan Hukum Dalam Upaya Perlindungan Hak Kelompok Rentan (Anak Dan Perempuan). Jurnal HAM, 7(2), 141-155. https://doi.org/http://dx.doi.org/10.30641 /ham.2016.7.141-155

Mia Kusuma Fitriana. (2015). Peranan Politik Hukum Dalam Pembentukan Peraturan Perundang-Undangan Di Indonesia Sebagai Sarana Mewujudkan Tujuan Negara. Jurnal Legislasi Indonesia, 12(02), 1-27.

Michael J.A. (2017). Press Freedom's Dark Horizon. In Freedom of the Press Report 2017 (Issue April).

https://freedomhouse.org/sites/default/file s/FOTP_2017_booklet_FINAL_April28.pdf

Nasrullah, R. (2019). Teori dan Riset Khalayak Media (Pertama). Kencana. 
Dedi Sahputra, Peran Wartawan Dalam Perlindungan Hak Anak

Pardede, M. (2017). Aspek Hukum Kebijakan Penyuluhan Hukum Dalam Rangka Pelaksanaan Sistem Peradilan Pidana Anak. Jurnal Penelitian Hukum De Jure, 17(1), 1328.

Ramli, T. S., Ramli, A. M., Budhijanto, D., Permata, R. R., Adolf, H., Damian, E., \& Palar, M. R. A. (2019). Prinsip-prinsip Cyber law Pada Media Over The Top E-Commerce Berdasarkan Transformasi Digital Di Indonesia. Jurnal Legislasi Indonesia, 16(3), 392-398.

Sahputra, D. (2019). Perlindungan Hak-Hak Anak dalam Perspektif Komunikasi Massa. Jurnal HAM, $\quad 10(2), \quad 233$. https://doi.org/10.30641/ham.2019.10.233 $-248$

Sahputra, D. (2020). Implementasi Hukum Pers Di Sumatera Utara. Jurnal Penelitian Hukum De Jure, 20(2), 259-274.

Stirling, K., Toumbourou, J. W., \& Rowland, B. (2015). Community factors influencing child and adolescent depression: A systematic review and meta-analysis. Australian and New Zealand Journal of Psychiatry, 49(10), 869886.

https://doi.org/10.1177/000486741560312 9.
Suara.com diakses pada Sabtu, 30 Mei 2020 pukul 07.05 Wib,

https://www.suara.com/health/2019/07/2 3/071000/anak-berhadapan-denganhukum-potret-buram-perlindungan-anak-diindonesia.

Tabroni, R. (2014). Komunikasi Politik Pada Era Multimedia (N. S. Nurbaya (ed.); Cetakan ke). Simbiosa Rekatama Media.

Tjipta Lesmana. (2017). Journalist as Professional versus Employee - a Case of Daily Koran Sindo in Censoring News on Trump's Travel-Ban Policy. 02(02), 109-119. https://doi.org/10.25008/jkiski.v2i2.108

Undang-Undang Nomor 11 Tahun 2012 Tentang Sistem Peradilan Pidana Anak. https://doi.org/10.1017/CB097811074153 24.004

Undang Undang Republik Indonesia Nomor 23 Tahun 2002 Tentang Perlindungan Anak.

Utami, R. R., \& Asih, M. K. (2016). Konsep Diri Dan Rasa Bersalah Pada Anak Didik Lembaga Pemasyarakatan Anak Kelas Iia Kutoarjo. Jurnal Indigeneous, 1(1), 84-91. https://doi.org/10.26623/jdsb.v18i1.563. 